\title{
RESEARCH ON MODELLING OF SPATIAL DYNAMIC STRUCTURAL MECHANICS AND SPATIO-TEMPORAL EVOLUTION OF COAL MINE STOPES
}

\author{
Zhi-jie Wen, Mikael Rinne, Zhen Song, Zuo-zhen Han, Jin-hao Wen
}

Original scientific pape

Major hazardous accidents in coal mines are basically attributable to a lack of understanding of or the failure to establish a complete spatial structural mechanical model of the stope during the course of exploitation, as well as of the spatial movement over time caused by the mining itself, mining at the wrong time, as well as improper roadway maintenance and advance of the work face. To efficiently study and analyze the mechanism behind major stope disasters, a method based on monitoring the stress and displacement of stopes was adopted to deduce the process whereby the overlying strata fracture, and a method of ascertaining stope stability based on qualitative identification of the dynamics was further proposed. The study found that the stability of stopes during the process of mining the face can be divided into two stages: (1) Unstable stage: i.e. the distance the work face has advanced $L_{x}<$ width of work face $L_{0}$; (2) Stable stage: i.e. the distance work face has advanced $L_{x}>$ width of work face $L_{0}$. These research results provide a basis for reasonable determination of a space-time relationship for the mining process.

Keywords: dynamic structure; spatiotemporal evolution; stability; stope

\section{Istraživanje modeliranja prostorno dinamičke strukturne mehanike i prostorno-vremenske evolucije iskopa ugljenokopa}

Velike pogibeljne nesreće u ugljenokopima u osnovi se pripisuju nedovoljnom razumijevanju ili propustu stvaranja potpunog prostornog strukturnog mehaničkog modela iskopa tijekom eksploatacije kao i prostornom gibanju do kojeg je tijekom vremena došlo zbog samog iskapanje, iskapanja u krivo vrijeme, kao i neodgovarajućeg održavanja kolnika i pomicanja radne površine. U svrhu učinkovitog proučavanja i analize mehanizma zbog kojeg dolazi do velikih nesreća, primijenjena je metoda zasnovana na praćenju naprezanja i pomicanja iskopa da bi se izveo postupak koji dovodi do loma gornjih slojeva, te je dalje predložena metoda utvrđivanja stabilnosti iskopa na temelju kvalitativne identifikacije dinamike. Proučavanjem se ustanovilo da se stabilnost iskopa tijekom vađenja rude može podijeliti u dvije faze: (1) nesigurna faza t.j. udaljenost za koju je radna površina pomaknuta $L_{x}<$ širine radne površine $L_{0} ;(2)$ sigurna faza t.j. udaljenost za koju je radna površina pomaknuta $L_{x}>$ širine radne površine $L_{0}$. Ti rezultati istraživanja čine osnovu za razumno određivanje odnosa prostor-vrijeme u postupku rudarenja.

Ključne riječi: dinamička struktura; iskop; prostorno-temporalna evolucija; stabilnost

\section{Introduction}

It is necessary to establish scientifically and accurately the relationship between the spatial fracture forms of surrounding rocks and the stress field of the rocks surrounding coal mine stopes in engineering practice based on specific situation of coal seams and mining conditions, and propose a corresponding motionspatiotemporal effect, thus laying a basis for mitigating accidents and environmental disasters during the process of advancing the face and tunnelling, and also during preparation for tunnel stoping in adjacent stopes and the process of stopping. Scholars both home and abroad have carried out relevant studies $1 \div 6$ on microseisms caused by the movement of strata overlying stopes, but there is as yet no in-depth study on the movement of strata overlying stopes, and more specifically, reasonable grounds for identifying stope stability. Based on spatial structural mechanical modelling of stopes, the relevance of characteristic fracture movements of overlying strata and the evolution of mining stress fields in stopes was studied, and a feasible mining space-time relationship for coal mines was proposed, providing new approaches and methods for quantitative research into coal mines.

This article explores the connection between the characteristic spatial evolution of the structure and the rules governing the evolution of mining stress fields in stopes based on results from 3-D monitoring of stope fractures using the Mining Abutment Stress Simulation System (MISSS), Mining Stress Monitoring System
(MISMS) and Large Deformation Monitoring System (LDMS), developed by the authors.

\section{Formulation of a structural mechanics model and structural characteristics at stopes}

The results of investigations into several major accidents in China show that the range of strata movement connected with accidents exceeds the range of what would generally be considered the "basic roof" (6 to 8 times the stope height) in the direction of thickness, and also exceeds the range adjacent to the upper and lower tunnels of the work surface in the level direction, namely, strata movement should be the focus for controlling the inner roof panels of the stope, while the timing of strata movement should be considered for controlling disasters around the stope. There are two main reasons for controlling movement timing, namely mining depth, as well as the composition and movement of the stratum spatial structure in the area surrounding the stope affected by the mining. Therefore, research on the control of stress in mines should, by focusing on stratum movement, give priority to studying the range of damage caused by overlying stratum movement during advance of the stope and the different characteristic structural components within the range, as well as rules for movement and development.

The spatial structure of the overlying strata in this article refers to the three-dimensional structure formed after fracture of the overlying strata, which plays a leading role in stope stress behaviour. 
According to our research and analysis, the stratum overlying a coal bed can be divided into the spatial structure of the overlying stratum and the spatial structure outside the overlying stratum, of which the spatial structure external to the overlying strata refers to strata that have generated no obvious movement outside the "fracture arch". The spatial structure of the overlying strata is formed by movement of the stratum structure inside the "fracture arch" that directly impacts on stress in the mine 7

Along with the advance of the work face (face width: $\left.L_{0}\right)$, the exposed space of the stope increases continuously, while the overlying strata also fracture continuously, and the fracture position alternates successively from bottom to top, forming a "fracture arch" with the fracture positions of each critical stratum as the boundary. Meanwhile, the stress in surrounding rocks of the spatial structure is redistributed, and the weight of the overlying strata loaded originally by the mining coal onto the work face is loaded onto the coal (or rock) on both sides. In this case, the load supported by the coal (or rock) on both sides is sourced from two parts within a certain range: (1) the stress generated inside the coal (rock) by the weight of the overlying stratum itself outside the "fracture arch"; (2) the stress transferred to the coal (rock) by the fracture rock beam inside the "fracture arch" of the stope. If the total stress loaded onto the coal (rock) exceeds its strength, it will fracture. The peak abutment stress will be transferred outwards. The rock beam undergoes this process each time it fractures. This is shown in Fig. 1.

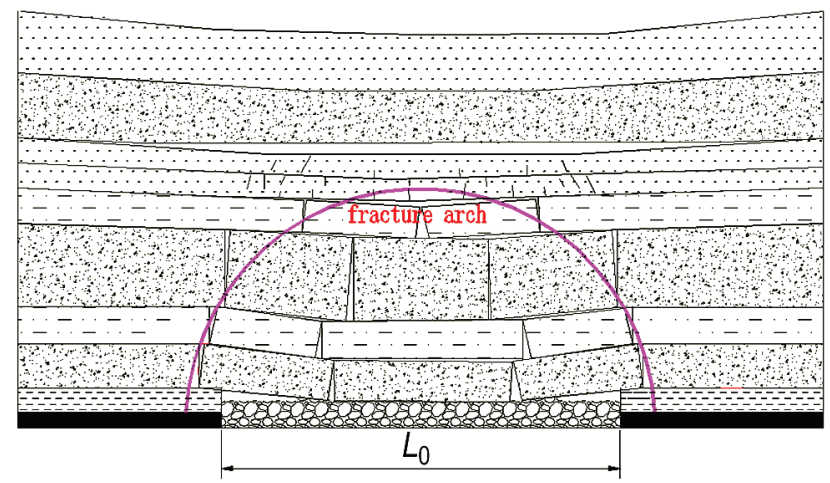

Figure 1 Schematic diagram of "fracture arch structure" model

\section{Relation between the spatial structural characteristics of the overlying stratum and evolution of the mine stress field}

The formation and stability of the mining stress field is an unfolding process related to the mining, and directly associated with the development and stability of the corresponding stratum movement. After mining, the spatial mechanical structure formed by the overlying strata is key to studies on controlling the stope stratum. The relationship between the evolution of abutment stress in a stope and movement of the overlying strata, as well as the interaction between brackets and the surrounding rock (roof) at the moment of stress constitute the basis for resolving the stress applied to stopes in the mining process and the problem of control thereof. Therefore, the goal of avoiding stressing in excess of a fixed target during tunnelling in the mining stress field not only depends on where the tunnel is dug, but also depends on when the tunnel is dug, thus integrating the time and place tunnels are dug. The complexity of the evolutions of abutment stress in the stope and factors influencing it, as well as the invisibility of the movement of overlying strata in practical research, bring great challenges to the theoretical study of mining stress. Restricted by configurations of testing points and the measurement tools in field studies, studies by scholars both home and abroad have been limited to the static analysis of stope stability, meaning that the problem of coming up with a stabilizing spatio-temporal effect has yet to be resolved. For these reasons, the present authors studied the evolution of the spatio-structural features of overlying strata and the rules governing the evolution of mining stress fields respectively in the laboratory and at stope sites, using the Mining Abutment Stress Simulation System (MISSS), Mining Stress Monitoring System (MISMS) and Large Deformation Monitoring System (LDMS) developed by the authors.

\subsection{Mechanical characteristics of the fracture of overlying strata and the evolution of mining stress fields}

MISSS was used to comprehensively and continuously monitor the dynamic evolution of mining stress during the fracturing of the overlying strata consequent to the advancing of the stope.

\subsubsection{Mining Abutment Stress Simulation System (MISSS)}

Mine stopes exist in three-dimensional geometric space, so mechanical analysis involves the relatively complex problem of space, making it difficult to analyze using experimental modelling. More importantly, the dynamic development of mining stress fields is inextricably linked to the range of damage to overlying longitudinal stratum, lending to simplification by approximating the problem to a plane. This is shown in Fig. 2 and Fig. 3.

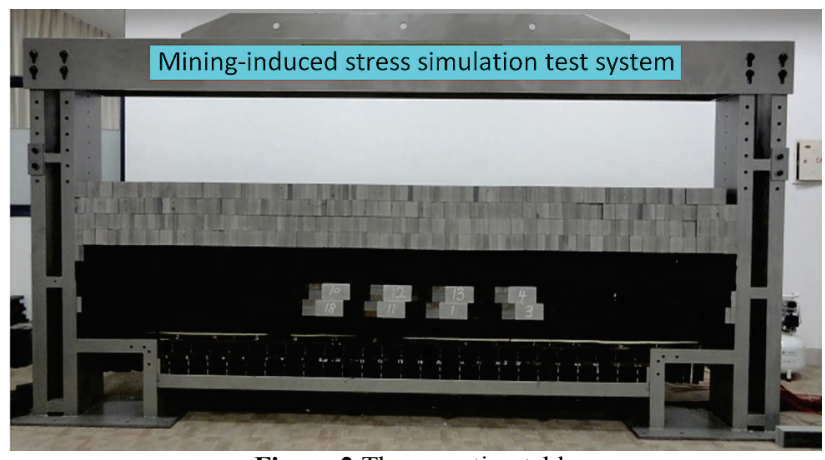

Figure 2 The operating table

The structure of the overlying strata of stopes is extremely complex, varying by mining conditions and lithology, but there is a definite range of overlying strata, which obviously affect the evolution of abutment stress in stopes. The space of the overlying strata is simplified into three critical strata, to facilitate research and analysis of the rules governing evolution of mining stress fields over the course of fracturing of successive critical strata. 


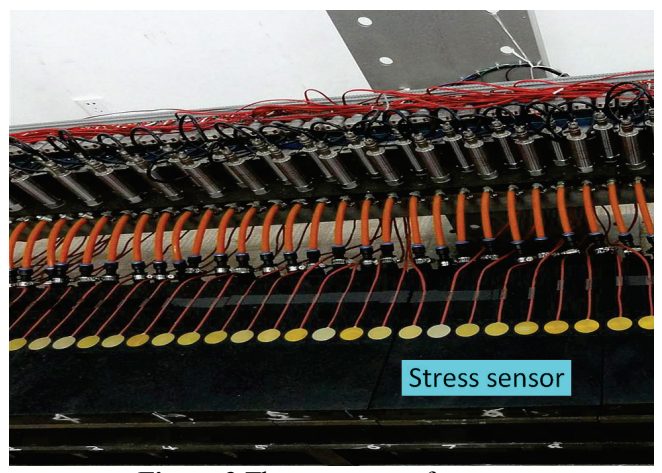

Figure 3 The test system for stress
The coal bed and overlying strata structure clearly impacting the stope stress were laid on the model rack in a certain sequence using rubber blocks, then connected like building blocks where the rubber blocks of each layer are in close succession to form a layer. The location of the fracture in the basic roof rock beam and stress increments were controlled manually by adjusting the position of an electromagnetic mechanism. The appearance and collection of abutment stress are measured using stress sensors embedded in the rubber blocks, with a total of 112 groups. This is shown in Fig. 4.

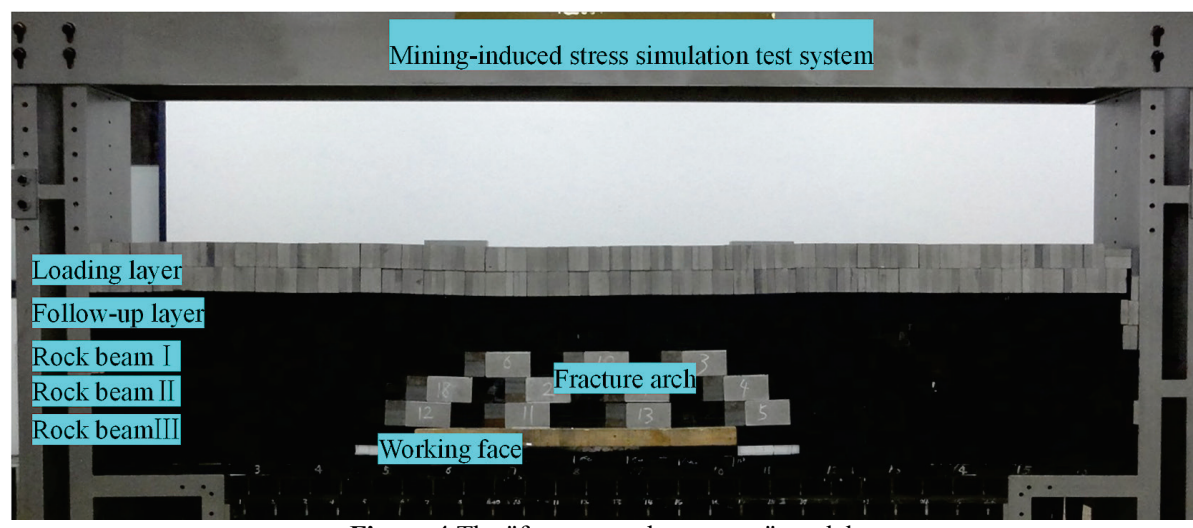

Figure 4 The "fracture-arch structure" model

\subsubsection{Results}

The width of the simulated work face was $100 \mathrm{~m}$, the height of the collapsed zone was $10 \mathrm{~m}$, and the mined-out area was filled with foam chips. Three rack beams were electrically discharged in order to simulate the evolution of abutment stress in the coal wall during the rolling fracture of the overlying stratum.

After the electromagnets $\mathrm{A}, \mathrm{B}, \mathrm{C}$ of the $1^{\text {st }}$ rock beam were discharged, and the $2^{\text {nd }}$ rock beam bears the weight of the overlying stratum, the load is transferred to both sides, where the coal on both sides withstands a larger acting force, and stress is transferred. The peak elastic stress of $29 \mathrm{MPa}$ is located at a place $10 \mathrm{~m}$ inside the coal wall, with a stress concentration factor of 1,81 . The fractured part of the 1 st rock beam acts on the foam chips, and the stress sensors monitor the mean stress in the mined-out area as $0 \div 0,2 \mathrm{MPa}$.

After electromagnets $\mathrm{A}, \mathrm{B}, \mathrm{C}$ of the $2^{\text {nd }}$ rock beam were discharged, the load carried by the coal at both sides reduces, with the reducing range limited to the fractured part of the $2^{\text {nd }}$ rock beam, therefore, the peak value of elastic stress should decrease. The measured value is 28 $\mathrm{MPa}$, with a stress concentration coefficient of 1,75 , while the mean stress in the mined-out area is about $0,4 \mathrm{MPa}$.

After the electromagnets $\mathrm{A}, \mathrm{B}, \mathrm{C}$ of the $3^{\text {rd }}$ rock beam were discharged, the "fracture-arch" structure forms and the peak value of the elastic stress at both sides is 27,5 $\mathrm{MPa}$, with a stress concentration coefficient of 1,72 , while the mean stress in the mined-out area is about $0,8 \mathrm{MPa}$.

After the "fracture-arch" is formed, the rock strata above the arch do not fracture any more due to the lack of fracture space, gradually sinking instead, and after a period of time, the stratum overlying the stope finally stabilizes, while the loaded part of the rock stratum above the arch acts on the "fracture-arch", part of which is transferred to both sides, the monitored peak value of coal bodies at both sides was $27,2 \mathrm{MPa}$, the stress concentration coefficient is 1,7 , while the stress at minedout area was about 1,0 MPa.

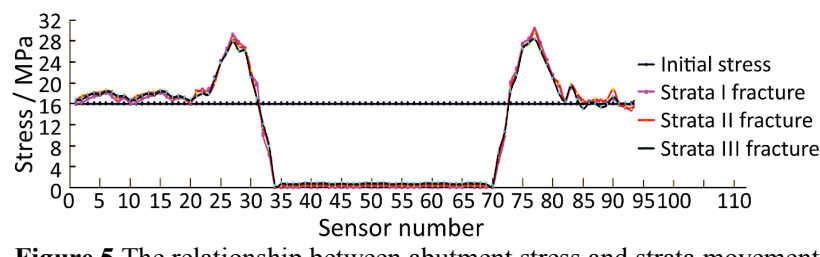

Figure 5 The relationship between abutment stress and strata movement

It can be seen from the results of the test that the elastic stress peak value decreases somewhat during the process of the successive fracturing of the rock beam, while the abutment stress on the coal outside the fracturing line increases with the fracturing of the rock beam. After completion of fracturing until stabilization of the overlying strata, the abutment stress in this range will continuously fall. A curve showing the change is shown in Fig. 5.

In conclusion, with the successive fracturing of the strata overlying the stope, the peak stress in the mining stress field tends to fall from high to low, owing to the fact that the fracturing of the strata overlying the stope causes a decline in transfer of the load to both sides.

\subsection{Monitoring the relationship between the fracturing of overlying strata and mining stress field}

The Mining Stress Simulation System (MISSS) and the Dynamic Monitoring System (DMS) developed for field application can monitor the structure and movement of rock strata and the characteristic evolution of mining 
stress in real time, so these systems enable real-time, comprehensive monitoring of dynamic data for strata overlying stopes.

The test site selected was Dongda Coal Mine work face 12301, with a coal bed at a depth of $650 \mathrm{~m}$, and width of work face of $120 \mathrm{~m}$.

\subsubsection{Indirect monitoring method - mainly for stress monitoring}

(1) Test Scheme

The test was configured with four test points, using the test instruments shown in Fig. 6, and configuration shown in Fig. 7, wherein the instruments are placed in coal in an elastic state; see Fig. 8 for the histogram of work face.

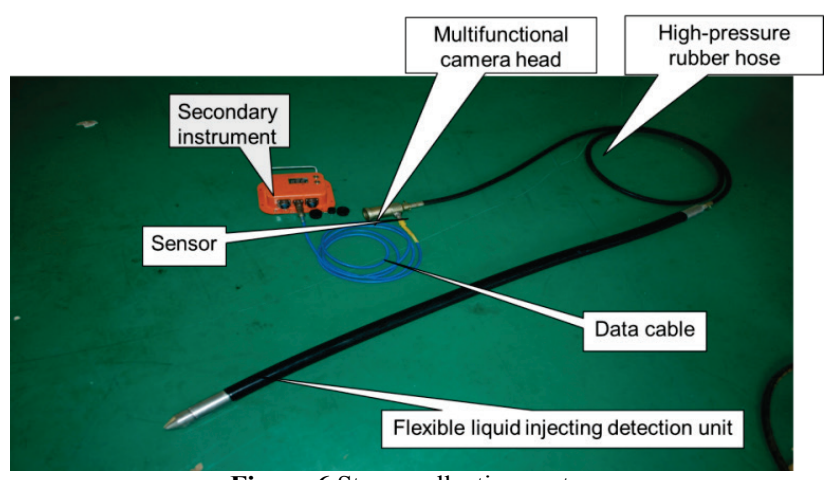

Figure 6 Stress collection system

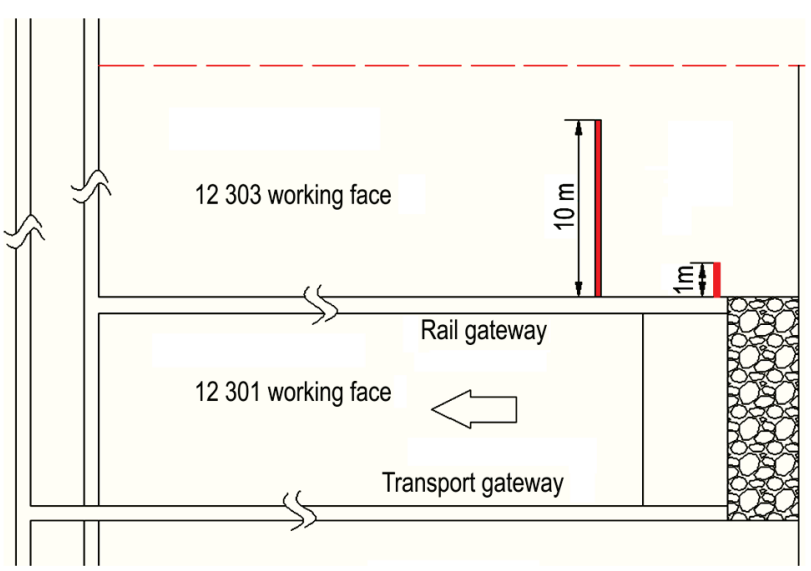

Figure 7 Configuration of test points

(2) Data processing

A probability-based statistical method was used to confirm parameters during the calculation of the maximum Lypaunov exponent in the time series, and the Fortran programming language was used to compile a program to calculate the maximum Lyapunov exponent.

Principles for program design: derive $L E_{1}$ from univariate time series using the Wolf method. As shown in Fig. 9, the univariate time series was reconstructed using an m-dimensional phase space, and the time lag $\tau$ that minimizes the relevance of phase space coordinates is selected, then, in the continuous m-dimensional phase space, the initial reference phase point is

$\mathrm{A}\left(t_{1}\right): x\left(t_{1}\right), x\left(t_{1}+\tau\right), \cdots, x\left(t_{1}+(m-1) \tau\right)$.

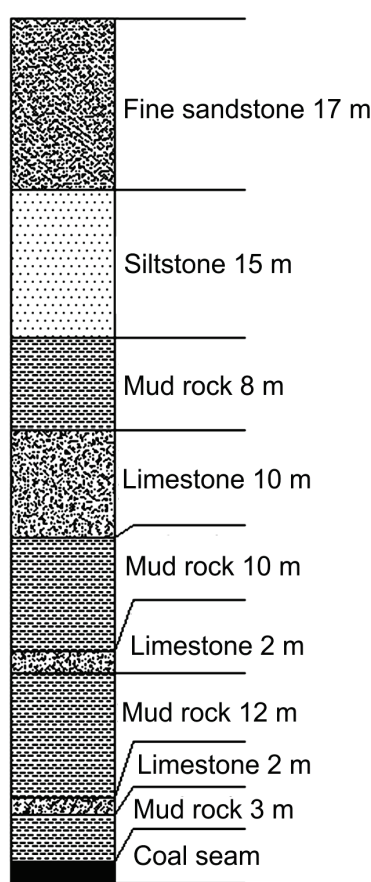

Figure 8 Strata histogram

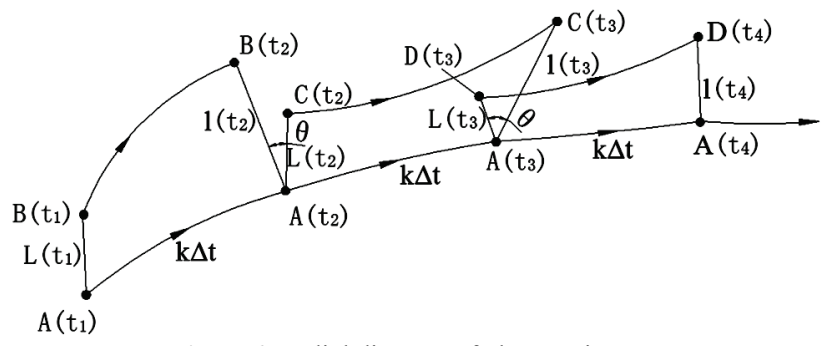

Figure 9 Radial diagram of phase trajectory

According to the formula for the distance between two points on the Euclidean space, the nearest neighboring point $\mathrm{B}\left(t_{1}\right)$ of the initial phase point $\mathrm{A}\left(t_{1}\right)$ can be acquired, with a spacing of $L\left(t_{1}\right)=\overline{A\left(t_{1}\right) B\left(t_{1}\right)}$. At the time $t_{2}=t_{1}+k \Delta t, \mathrm{~A}\left(t_{1}\right)$ and $\mathrm{B}\left(t_{1}\right)$ evolve separately into $A\left(t_{2}\right)$ and $B\left(t_{2}\right)$, the spacing between $\mathrm{A}\left(t_{2}\right)$ and $\mathrm{B}\left(t_{2}\right)$ is $l\left(t_{2}\right)=\overline{A\left(t_{2}\right) B\left(t_{2}\right)} . \quad \lambda_{1}$ is used to represent the index growth rate of line segments over the time period, therefore:

$\lambda_{1}=\frac{1}{k \Delta t} \ln \frac{l\left(t_{2}\right)}{L\left(t_{1}\right)}$

The rest may be deduced by analogy up the end of $x_{i}$ point set, here, $i=1,2, \ldots n^{\prime}$ and

$n^{\prime}=N N-m \tau-k \Delta t$,

where: $N N$ is the sample space of time sequence, $\mathrm{m}$ is the embedded median, $\tau$ is the time lag, and $k \Delta t$ is the step.

Take the average of the $n^{\prime}$ index growth rate as the estimate of $L E_{1}$ under this embedding dimension, i.e.

$L E_{1}(m)=\frac{1}{N} \sum_{i}^{N} \frac{i}{k \Delta t} \frac{l\left(t_{i}\right)}{L\left(t_{i}-1\right)}$ 
where: $N$ is the total steps of evolution, and $N=\frac{n^{\prime}}{k \Delta t}$.

(3) Identification of the stability of overlying strata movement in the stope.

Select 722 groups of representative monitoring data series for Lyapunov exponent calculation. Delay $\tau=2 \div$ 6 , calculating step: step $=1 \div 4$. If the delay and calculation step are not selected appropriately, they will present a discrete trend with weak regularity, and the convergent saturated embedding dimensionality and Lyapunov exponent cannot be determined. When delay $\tau=3$ and calculation step: step $=2$, the Lyapunov exponent gradually stabilizes with increase in the space dimensionality of the reconstructed phase space, with the space dimensionality of the saturated reconstructed phase $m=11$.

Quantitative dynamic analysis was carried out on the monitored characteristic data of stress variation of the coal wall. The Lyapunov exponent of each group of time series was acquired by changing the embedded dimensionality $m$ for the phase space reconstruction. The Lyapunov exponent allows for representation of the macroscopic and overall properties of the system, rather than local representation, so it is one measurement of the mean convergence or mean divergence of the neighboring orbits in the phase space. The Lyapunov exponent or symbol reflects the state of the system: when $L E>0$, the system is in unstable state; when $L E<0$, the phase volume of the system is shrinking, the orbit is partially stable, and not sensitive to initial conditions. When $L E=0$, the system is in a stable state correspondingly to the stable boundary. So $L E$ is of great practical value for assessing system stability.

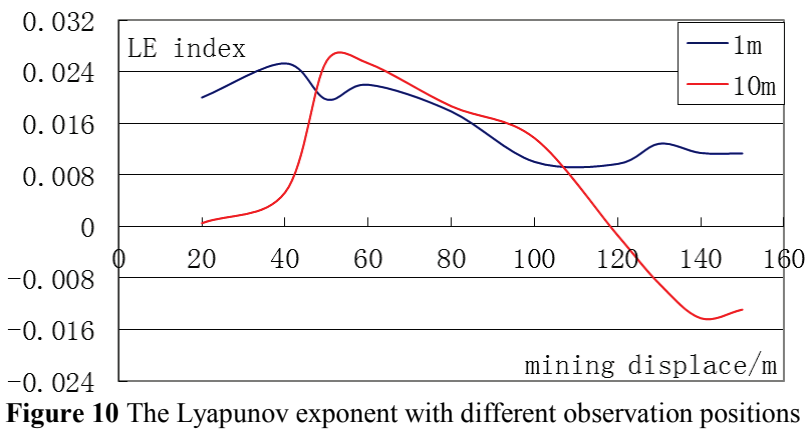

Fig. 10 depicts a flexible detecting unit that enables monitoring of the calculated curve of the Lyapunov exponent as the work face is advanced at a depth of $1 \mathrm{~m}$ and $10 \mathrm{~m}$. Delay $\tau=3$, calculation step: step $=2$.

It can be seen by analysis of Fig. 10:

(1) When the monitored location is at a depth of $1 \mathrm{~m}$, i.e., the instrument is placed within range of the "fracture arch", the Lyapunov exponent $L E>0$, the system is unstable, i.e., plastic deformation occurs within $1 \mathrm{~m}$ of the coal, and this depth is inappropriate.

(2) when the monitored location is at a depth of $10 \mathrm{~m}$, i.e., the instrument is placed within range of the "stress arch", and the work face has advanced $60 \div 100 \mathrm{~m}$, the system is quite unstable, indicating that the strata overlying the stope are in the process of fracturing. After the distance advanced exceeds $120 \mathrm{~m}, L E<0$, the fracturing process of the strata overlying the stope comes to its completion and gradually stabilizes.

To summarize, the MISMS can be used to effectively predict the stability of the stope by monitoring the lateral stress during the process of advancing the stope. When the distance the stope has advanced $L_{x}$ is smaller than the work face width $L_{0}$, the overlying strata are in the process of fracturing and the stope is unstable, while when the distance advanced $L_{x}$ is greater than the work face width $L_{0}$, the stope is in a stable state.

\subsubsection{Direct monitoring method - mainly for displaced monitoring}

\section{(1) Testing scheme}

Two test points are configured. Please see Fig. 8 for a histogram of the work face, see Fig. 11 for the test instruments, and Fig. 12 for the configuration.

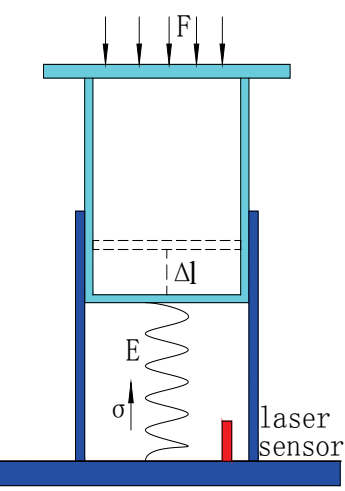

Figure 11 Schematic diagram of instrument principle

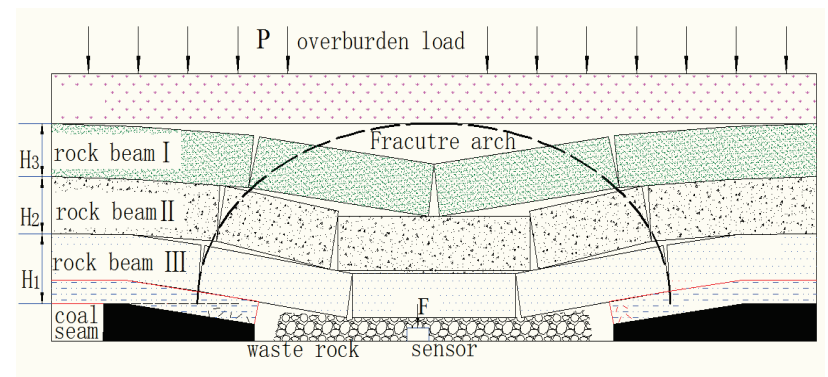

Figure 12 Structural model of stope

(2) Operating principles of the equipment

During the process of advancing the stope, the difference in lithological characteristics of the overlying strata leads to differences in the characteristic fracturing of the overlying strata, and obvious fragmentation over time. Meanwhile, bending and fracture of overlying strata will dynamically impact the mined-out zone. Therefore, during the formation and development of the mechanical structure of the strata overlying the stope, the DMS placed in the mined-out zone can be used to effectively monitor the spatial structure and dynamic characteristics of the stope.

Mechanical equilibrium equation of the system is

$F(\varepsilon)=E \cdot \Delta l \cdot S=A \cdot \Delta l(t)=\rho \cdot g \cdot H \cdot S$,

where: $F$ - overburden load $(\mathrm{N}) ; E$ - modulus of elasticity: $0,6 \mathrm{GPa} ; \rho-$ strata density $\left(\mathrm{kg} / \mathrm{m}^{3}\right) ; S-$ area 
between system and waster rock: $0,07065 \mathrm{~m}^{2} ; H$ - strata height (m); $\Delta l$ - compression distance (m);A $=E \cdot S$.

From Eq. (4), the thickness of the overlying strata acting on the stress sensor can be obtained:

$$
H=\frac{F}{\rho \cdot g \cdot S} \text {. }
$$

If the first critical layer fractures, the force acting on the monitoring system:

$$
F_{1}=A \cdot \Delta l_{1}=\rho_{1} \cdot g \cdot H_{1} \cdot S_{1}, \quad H_{1}=\frac{F_{1}}{\rho_{1} \cdot g \cdot S_{1}} .
$$

The range of fracture in the second and third critical layers can be similarly obtained:

$$
H_{2}=\frac{F_{2}}{\rho_{2} \cdot g \cdot S_{2}}, \quad H_{3}=\frac{F_{3}}{\rho_{3} \cdot g \cdot S_{3}} .
$$

(3) Determining the stability of the stope

The instrument is placed in the mined-out zone at a distance where the work face has advanced $40 \mathrm{~m}$ for realtime monitoring of the movement of the overlying strata during advancing of the stope. The curve obtained by monitoring is shown in Fig. 13, and the results of analysis are listed in Tab. 1.

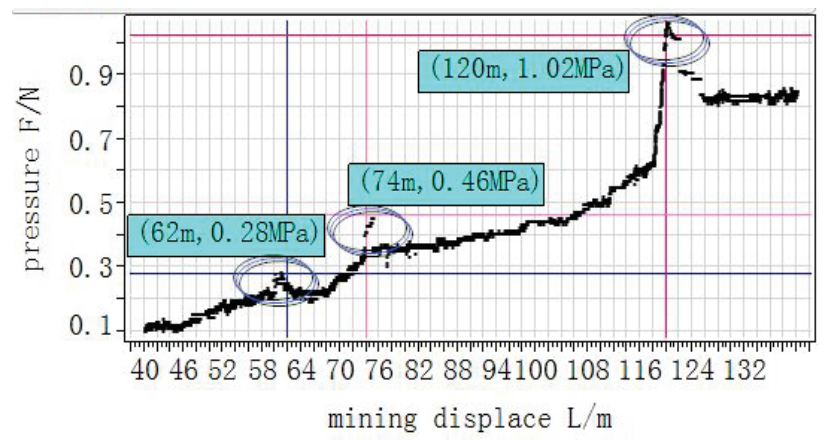

Figure 13 Monitored data (instrument radius of $0,15 \mathrm{~cm}$ )

Table 1 Table of fracture dynamics of overlying strata

\begin{tabular}{|c|c|c|c|c|c|}
\hline Fracture stratum & $\begin{array}{c}\text { Fracture } \\
\text { location }\end{array}$ & $\begin{array}{c}\text { Impact load } \\
\left(10^{6} \mathrm{~N}\right)\end{array}$ & $\begin{array}{c}\text { Stable load } \\
\left(10^{6} \mathrm{~N}\right)\end{array}$ & $\begin{array}{c}\text { Fracture range } \\
(\mathrm{H} / \mathrm{m})\end{array}$ & Actual fracture range $(\mathrm{H} / \mathrm{m})$ \\
\hline $\begin{array}{c}\text { First critical } \\
\text { layer }\end{array}$ & $\begin{array}{c}\text { Advancing } \\
\text { distance } 62 \mathrm{~m}\end{array}$ & 0,28 & 0,20 & 11,30 & 15 (mudstone $3 \mathrm{~m}$, limestone 2 m, mudstone 12 m) \\
\hline $\begin{array}{c}\text { Second critical } \\
\text { layer }\end{array}$ & $\begin{array}{c}\text { Advancing } \\
\text { distance } 74 \mathrm{~m}\end{array}$ & 0,46 & 0,36 & 9,08 & 12 (limestone 2 m, mudstone 10 m) \\
\hline $\begin{array}{c}\text { Third critical } \\
\text { layer }\end{array}$ & $\begin{array}{c}\text { Advancing } \\
\text { distance } 120 \mathrm{~m}\end{array}$ & 1,02 & 0,82 & 26,04 & 33 (limestone $10 \mathrm{~m}$, mudstone $8 \mathrm{~m}$, siltstone $15 \mathrm{~m})$ \\
\hline
\end{tabular}

During the process of advancing the work face coupled with the process of "formation - development stabilization" of the mechanical structure of the stope, the DMS in the stope accurately captured two states covering three dynamic impacts and two stables states of the stope. When the distance advanced was less than the width of the work face $(120 \mathrm{~m})$, there were three large fluctuations in the monitoring curve, corresponding to the successive fracture of the three critical layers, while waste rock collapse into the mined-out area, and the stope was in an unstable state. When the distance advanced was equal to or greater than the width of the work face $(120 \mathrm{~m})$, the monitored curve tended to stabilize, and the mechanical structure reached a stable state, and the strata overlying the stope no longer fractured, while there was only the compaction of waste rock in the mined-out zone. Meanwhile, the thickness of each critical layer can be calculated from the stable load by Eq. (2) and compared with the actual histogram. After analysis, a good correlation was seen. See table 1 for the results.

\section{Prospects for application of academic review of overlying strata spatial dynamic mechanics structure in mining engineering}

The proposed academic review and practice of the view of the spatial dynamic mechanical structure of overlying strata and related research methods can provide a further insight into the laws governing strata movement over a broader range under multiple boundary conditions. In mining engineering, these have great theoretical and practical significance in determining the height of fractured zones with flowing water, raising the upper limit of mining, predicting rock burst and coal/gas burst, etc., and is especially useful for deep mining.

\section{Conclusion}

Given the engineering characteristics of continual advance of coal stopes, it is necessary to correctly point out that with the advancing of the stope, both the spatial structure and the stress field of the coal stope undergo constant development and change, which are wellregulated and governed by the stratum movement. Therefore, the research press into the regulation of stress in mines should, by focusing on the stratum movement, focus on the range of damage by the overlying strata movement and evolutionary characteristics of stress distribution during stope advance under different mining conditions.

The area that has obvious effect on the mining stress in the stope in the 3D spatial structure is defined as the "fracture arch". The correlation between stratum fracture in the "fracture arch" and the evolution of the mining stress field can be obtained by monitoring with the MISSS, i.e., after stratum fracture, the peak value of the mining stress field will gradually fall.

A reasonable relationship between mining time and space for coal mines has been quantitatively determined. In the identification of spatial structure and stability of strata overlying stopes, MISMS can identify the spatial structural stability of the overlying strata during stope advance. DMS can well identify the spatial structure and stability of the overlying strata. It has been discovered 
from research that: the stope stability of the work face during the mining process can be divided into two stages: (1) the unstable stage, i.e., when the distance the work face has advanced, $L_{x}<$ width of the work face $L_{0}$, the developing height of the spatial overlying strata structure increases with the advancing of work face, coupled with transfer of mining stress; (2) the stable stage: i.e., when the distance the work face has advanced $L_{x}>$ width of work face $L_{0}$, after "mining" of the mined-out zone, the developing height of the spatial overlying strata structure reaches its maximum height at the width of this work face, while mining stress tends to stabilize. These research results can provide a basis for further determining a space-time relationship for mining.

\section{Acknowledgement}

This work is supported by National Basic Research Program of China under Grant No. 2012CB72310402, National Natural Science Foundation of China under Grant No. 51244010, No. 51304126 and No. 51374046, Science Research Innovative Group of College of Resources and Environmental Engineering of SDUST No. 2012ZHTD06. New Teachers' Fund for Doctor Stations of Ministry of Education under Grant No. 20123718120009. Open Project of State Key Laboratory Breeding Base for Mining Disaster Prevention and Control (Shandong University of Science and Technology)(MDPC2012ZR01). The research fund for excellent young and middle-aged scientists of Shandong Province under Grant No. 2013BSB01119. Fok Ying Tung Education Foundation under Grant No. 141046.

\section{References}

[1] Cai, M.; Kaiser, P. K.; Martin, C. D. Quantification of Rock Mass Damage in Underground Excavations from Microseismic Event Monitoring. // Int. J. Rock Mech. Min. Sci. 38, 8(2001), pp. 1135-1145. DOI: 10.1016/S13651609(01)00068-5

[2] Abdul-Wahed, M. K.; Heib, M. A.; Senfaute, G. Mininginduced seism city: Seismic Measurement Using Multiple Approach and Numerical Modeling. // Int. J. Coal Geo. 66, 1-2(2006), pp. 137-147.

[3] Jiang, F. X.; Zhang, X. M.; Yang, S. H.; Luo, X. Discussion on Overlying Strata Spatial Structures of Long Wall in Coal Mine. // Chinese J. Rock Mech. and Eng. 25, 5(2006), pp. 979-984.

[4] Fujii, Y.; Ishijima, Y.; Deguchi, G. Predication of Coal Face Rock Burst and Microseismicty in Deep Longwall Coal Mine. // Int. J. Rock Mech. Min. Sci. 34, 1(1997), pp. 85-96. DOI: 10.1016/S1365-1609(97)80035-4

[5] Mao, X. B.; Miao, X. X.; Qian, M. G. Study on Broken Laws of Key Strata in Mining Overlying Strata. // J. of China University of Min.Tec. 27, 1(1998), pp. 39-42.

[6] Miao, X. X.; Qian, M. G. Broken Feature of Key Strata and Its Influence on Rock Pressure in Super-length Fullymechanized Coal Face. // J. Rock Mech. Eng. 22, 1(2006), pp. $45-$

[7] Wen, Z. J. Study on the Key Technologies and Mechanical Model of Gob-side Retaining Entry. // PhD. Thesis. Shandong University of Science and Technology, 10-35 (in Chinese)(2011)

[8] Tan, Y. L.; Zhao, T. B.; Xiao, Y. X. Researches on Floor Stratum Fracturing Induced by Antiprocedure Mining
Underneath Close-distance Goaf. // Int. J. Min. Sci. 46, 3(2010), pp. 250-259. DOI: 10.1007/s10913-010-0032-7

[9] Tiwary, R. K.; Ral, K. N. Phase Space Structure, tractor Dimension, Lyapunov Exponent and Nonlinear Prediction from Earth's Atmospheric Angular Momentum Time Series. // Pure appl. Geophys. 15, 6(1999), pp. 719-736. DOI: $10.1007 / \mathrm{s} 000240050321$

[10] Albano, A. M.; Muench, J.; Schwartz, C. et al. Singularvalue Decomposition and the Grassberger-Procaccia algorithm. // Phys. Rew. A. 38, (1998), pp. 3017-3026. DOI: 10.1103/PhysRevA.38.3017

[11] Lin, Z. S. Nonlinear Dynamics and Atmospheric Science. Nanjing: Nanjing University Press, 112-120 (in Chinese) (1993).

[12] Wei, G.; Hong, J.; Wei, X. J. Research on Threedimensional Soil Deformation induced by Double-O-Tube Shield Tunneling. // Disaster Advances. 5, 4(2012), pp. 4-8.

[13] Guo, Ying-Qing; Xu, Zhao-Dong. Earthquake Disaster Mitigation by using Magneto-rheological dampers. // Disaster Advances. 5, 4(2012), pp. 540-545.

[14] Peng, Ningbo; Yan, Zhixin. Dynamic responses of anchored rock slope under earthquake - A numerical study. // Disaster Advances. 6, 2(2013), pp. 678-683.

[15] Wei, Bowen; Gu, Chongshi; Liu, Dawen; Zheng, Fugang. Analysis on instability of bedding slope disaster induced by snowmelt. // Disaster Advances. 5, 4(2013), pp. 849-853.

\section{Authors' addresses}

\section{Zhi-jie Wen}

State Key Laboratory of Mining Disaster Prevention and Control Co-founded by Shandong Province and the Ministry of Science and Technology, Shandong University of Science and Technology. 579 Qianwangang Road, Economic \& Technical Development Zone, Qingdao Shandong Province, 266590 Qingdao, P. R. China

Aalto University, FI-00076 Aalto, Finland

E-mail: sdust0532@gmail.com

\section{Mikael Rinne}

Aalto University, FI-00076 Aalto, Finland E-mail: mikael.rinne@aalto.fi

\section{Zhen Song}

Aalto University, FI-00076 Aalto, Finland

E-mail: zhen.song@aalto.fi

\section{Zuo-zhen Han}

State Key Laboratory of Mining Disaster Prevention and Control Co-founded by Shandong Province and the Ministry of Science and Technology, Shandong University of Science and Technology. 579 Qianwangang Road, Economic \& Technical Development Zone, Qingdao Shandong Province, 266590 Qingdao, P. R. China E-mail: hanzz@136.com

\section{Jinhao Wen}

State Key Laboratory of Mining Disaster Prevention and Control Co-founded by Shandong Province and the Ministry of Science and Technology, Shandong University of Science and Technology. 579 Qianwangang Road, Economic \& Technical Development Zone, Qingdao Shandong Province, 266590 Qingdao, P. R. China E-mail:Wenjh0532@163.com 